ская, 27, Киев, 01601, украина. Тел.+38(050)9342881.E-mail: eugenio.solonitsyn@gmail. com. ORCID: 0000000170571405.

Проценко Владимир Викторович - доктор медиинских наук, профессор, ведущий научный сотрудник отдела патологии стопы и сложного протезирования Ду "Институт травматологии и ортопедии НАМН Украины”, ул. Бульварно-Ккдрявская, 27, Киев, 01601, Украина. Tел. +38(050)3803781.E-mail: ip15@ukr.net. ORCID: 0000000188968371.

Для кореспонденції: Проценко Володимир Вікторович, вул. Бульварно-Кудрявська, 27, Київ, 01601, Україна. Тел. +38(050)3803781. E-mail: ip15@ukr.net.

For correspondence: Protsenko Volodymyr V., 27 Bulvarno-Kudriavska St., Kyiv, 01601, Ukraine. Tel. +38(050)3803781. E-mail: ip15@ukr.net.

Для корреспонденции: Проценко Владимир Викторович, ул. Бульварно-Кудрявская, 27, Киев, 01601, Украина. Тел. +38(050)3803781. E-mail: ip15@ukr.net.

УДК: 617.576-089(091)(477)

DOI: $10.37647 / 0132-2486-2020-105-2-75-82$

\title{
Development of Hand Surgery in Ukraine
}

\author{
Strafun S.S. ${ }^{1}$, Borzykb O.V. ${ }^{2}$, Kurinnyi I.M. ${ }^{1}$, Ivchenko D.V. ${ }^{3}$, Bilyi S.I. ${ }^{4}$, \\ Tymoshenko S.V. ${ }^{1}$, Lieskov V.H. ${ }^{1}$, Yarova M.L. ${ }^{1}$, Lysak A.S. ${ }^{1}$ \\ ${ }^{1}$ SI "Institute of Traumatology and Orthopedics of NAMS of Ukraine", Kyiv, Ukraine \\ ${ }^{2}$ National Military Medical Clinical Center "Main Military Clinical Hospital" \\ of the Ministry of Defense of Ukraine, Kyiv, Ukraine \\ ${ }^{3} \mathrm{MNE}$ "Emergency and Ambulance City Hospital" \\ of Zaporizhzbia City Council, Zaporizhzhia, Ukraine \\ ${ }^{4} \mathrm{MNE}$ "City Clinical Hospital No 16" of the Dnipro City Council, Dnipro, Ukraine
}

Summary. During the period of rapid industrialization, there was a need to create a new approaches to treat hand injuries due to rapid development of metallurgical, mining and engineer industry, which were accompanied by a bigh level of injuries with a significant amount of disability in the second half of 20 th century, in Donetsk, Dnipropetrousk and Kharkiv regions. New stage in the development of hand surgery and microsurgery in Ukraine began in the 80's: the Department of Microsurgery and Reconstructive Surgery of the Upper Extremity under the direction of I. Antoniuk was opened on the basis of the SI "Institute of Traumatology and Orthopedics of NAMS of Ukraine" in Kyiv in 1982. Development of hand surgery in the western regions of Ukraine began in the 90's. In Lviv, on the initiative of O. Toropouskyi, on the basis of the City Hospital No 8, a Center of Microsurgery and Surgery of the Hand was created. In Zakarpattia (Uzhborod) since 1997, on the initiative of V. Haiovich and A. Pogoriliak, microsurgery and hand surgery service was established, which is now under the care of the Combustiology Department. In Volyn (Lutsk), band surgery service is transmitted to the initiative group, also working at the City Combustiology Center. In Ivano-Frankivsk, Chernivtsi, Ternopil and Rivne, initiative groups in the field of hand surgery service bave been formed in the structure of orthopedics and traumatology departments. 2005 was marked by the opening of another center for surgery of the hand in Lubansk on the initiative of $V$. Ivchenko and under the guidance of $V$. Golovchenko, whose surgeons owned microsurgical equipment and provided highly skilled assistance to the population of this region. Ukrainian Hand Surgery Society (UHSS) was created in 2012, and led by Professor S. Strafun, as a result of collaboration of all hand surgery centers. In 2014, UHSS was accepted into the Federation of European Societies for the Surgery of the Hand (FESSH).

Key words: hand surgery; history of hand surgery; hand surgery in Ukraine. 


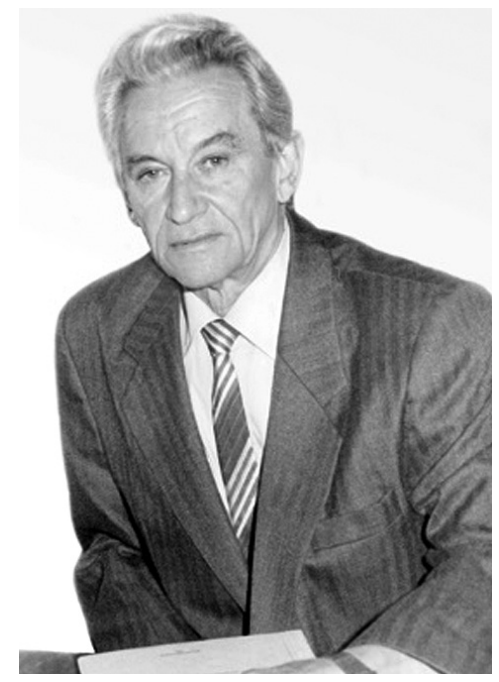

Yu. Kolontai

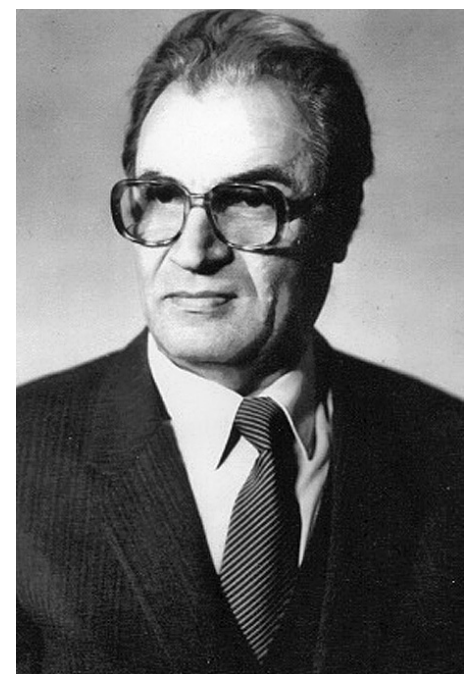

I. Antoniuk

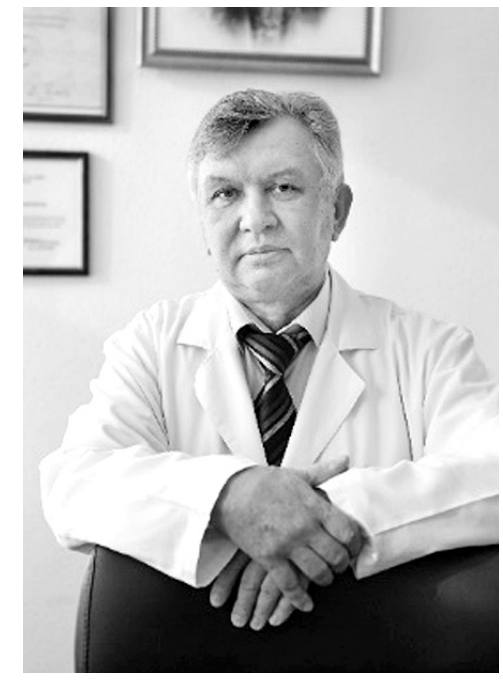

O. Borzykh
During the period of rapid industrialization, there was a need to create a new approaches to treat hand injuries due to rapid development of metallurgical, mining and engineer industry, which were accompanied by a high level of injuries with a significant amount of disability in the second half of 20th century, in Donetsk, Dnipropetrovsk and Kharkiv regions.

Department of Maxillofacial Surgery in Donetsk was re-profiled in a 40-bed traumatological department to assist patients with hand diseases and injuries and their consequences under the direction of R. Lyba in 1970. Under the direction of M. Andruson, the Department of Skin and Plastic Surgery on the basis of the SI "Sytenko Institute of Spine and Joint Pathology of NAMS of Ukraine" was established in the beginning of 1972 in Kharkiv, and in 1974, on the basis of the Dnipropetrovsk City Hospital No 2, 20 beds were allocated for patients with hand injury on the initiative of Yu. Kolontai.

New stage in the development of hand surgery and microsurgery in Ukraine began in the 80's: the Department of Microsurgery and Reconstructive Surgery of Upper Extremity under the direction of I. Antoniuk was opened on the basis of the SI "Institute of Traumatology and Orthopedics of NAMS of Ukraine" in Kyiv in 1982.

Interregional departments of surgery of the hand were opened same year, in Dnipropetrovsk under the direction of A. Hulai and Yu. Kolontai on the basis of the City Hospital No 2; in 1985, in Kharkov under the direction of O. Chuchelin on the basis of the City Hospital No 3; and in 1987, in Donetsk under the direction of O. Borzykh on the basis of the Regional Traumatological Hospital.

During the 80-90's, hand surgeons from all regions of Ukraine took care of the following issues: surgery and rehabilitation of finger flexor and extensor tendons; upper extremity peripheral nerves and brachial plexus surgery; treatment and prevention of hand ischemic contracture; creation of the system of reconstructive surgical treatment in case of neglected brachial plexus and peripheral nerves injuries; development of a system of reconstructive surgical treatment in case

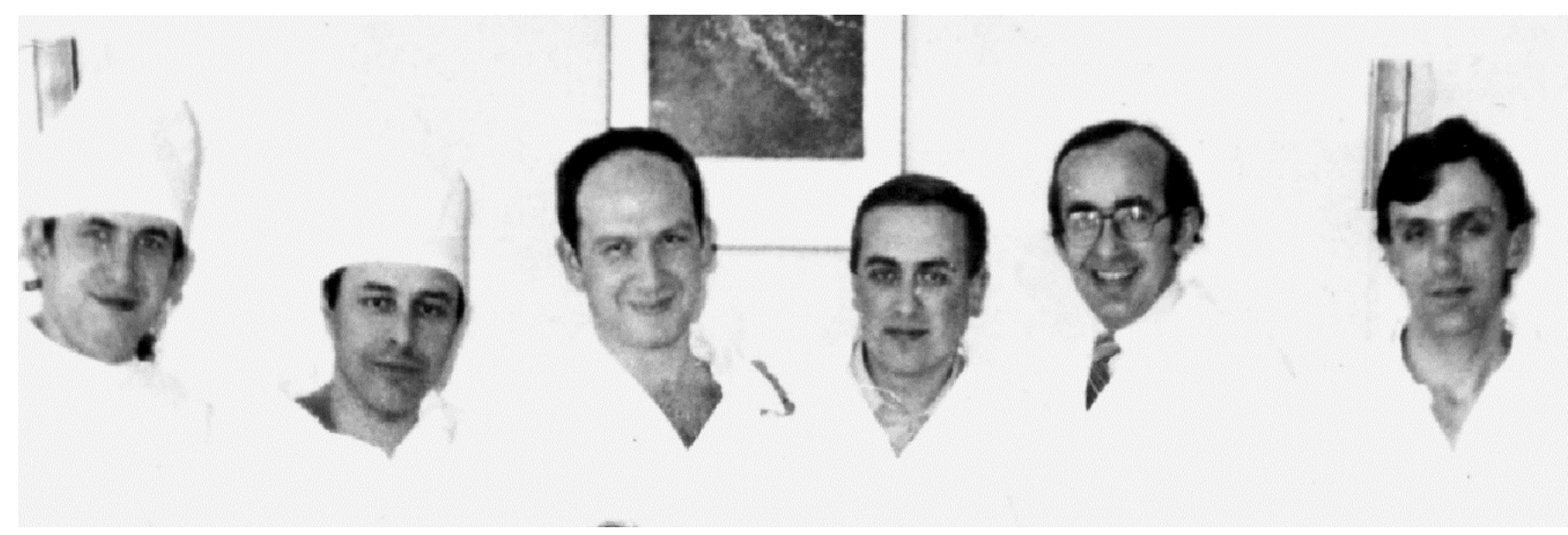

First surgeons of the Department of Microsurgery and Reconstructive Surgery of the Upper Extremity. Left to right: V. Leskov, O. Movchan, A. Liabakh, S. Strafun, V. Haiovich, I. Kurinnyi 


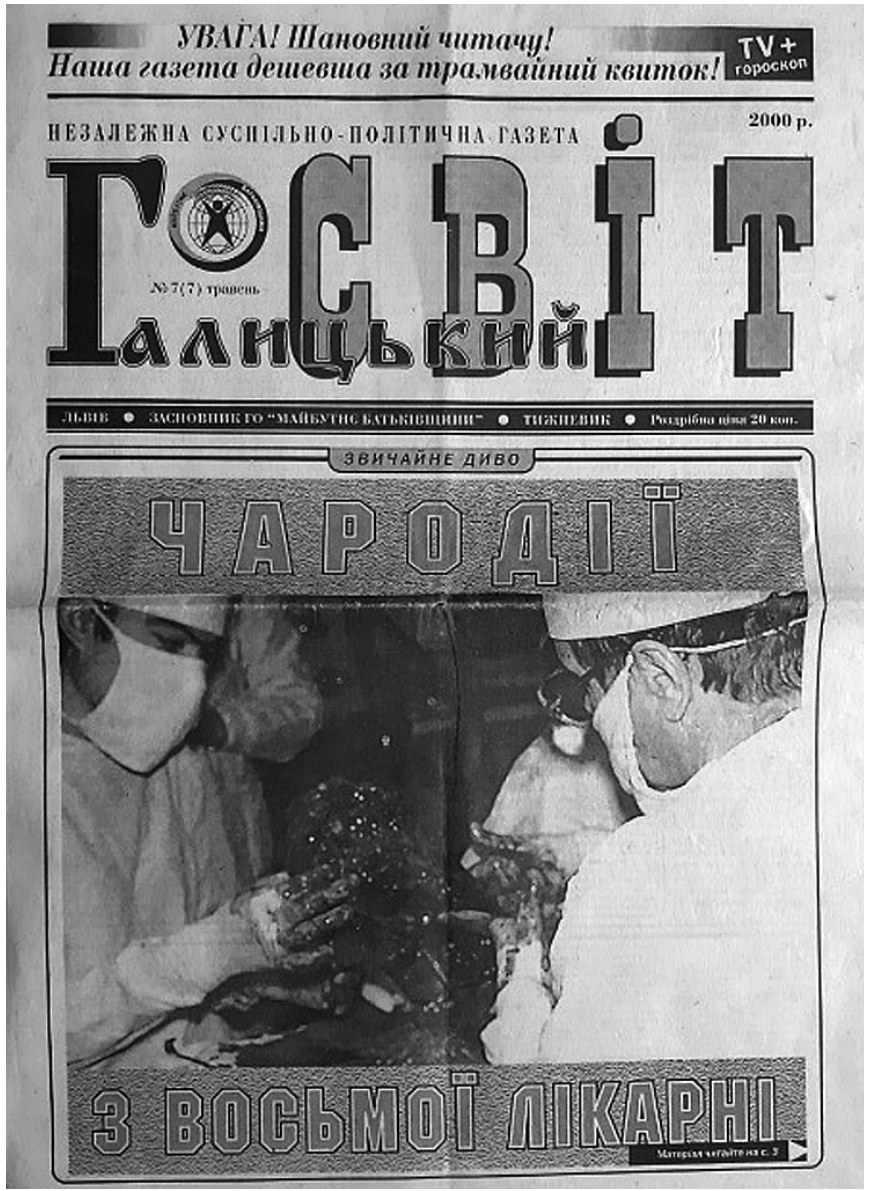

Newspaper Headline: Magicians from Eighth Hospital. About microsurgical limb replantation in Lviv

of polystructural upper extremity trauma, including gunshot wounds; surgical treatment of Dupuytren's contracture; treatment of tendinopathy; reconstructive interventions for upper extremity fractures and their consequences; treatment of congenital pathology of the hand; development of external fixation devices for hand fractures treatment; replantation of the upper extremity segments.

In October 1985, on the initiative of the Dnipropetrovsk Center for Surgery of the Hand, monothematical conference "Treatment of Hand Injuries and Their Consequences" was held for the first time in Ukraine. In

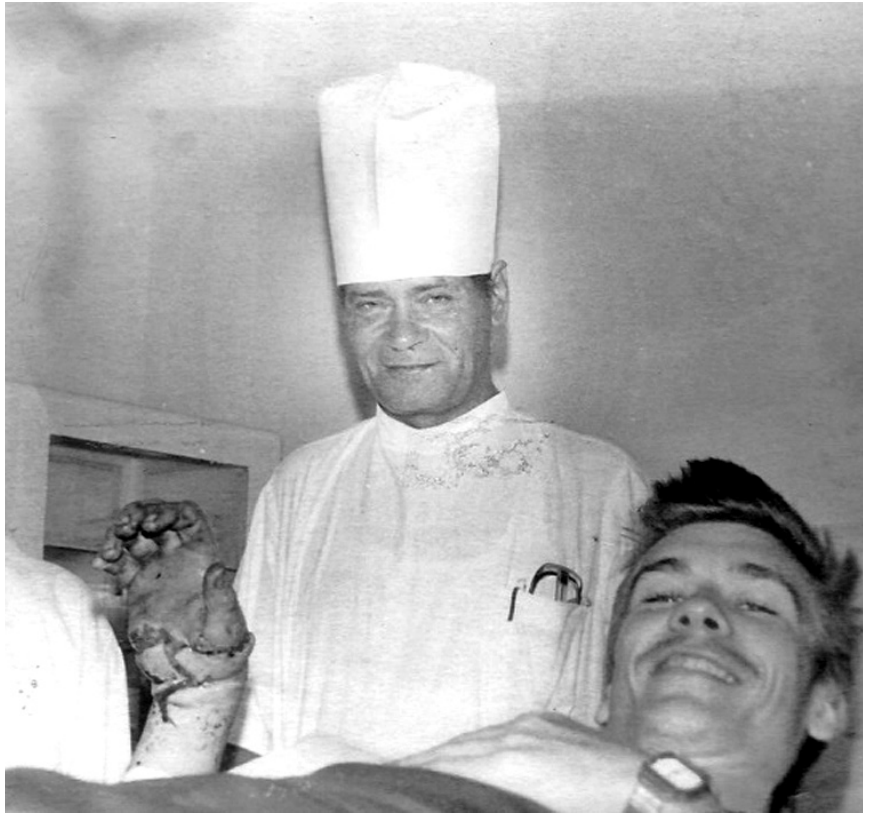

O. Toropovskyi and his patient after a successful hand replantation

1992, first Ukrainian (with international participation) scientific and practical conference on surgery of the hand "Hand Injury: Primary Care and Rehabilitation of Patients" was held, and was attended by 137 delegates from Ukraine, Russia, and Belarus.

The Republican Center for Surgery of the Hand was established on the basis of the Department of Microsurgery and Reconstructive Surgery of the Upper Extremity of the SI "Institute of Traumatology and Orthopedics of NAMS of Ukraine" in 1988. Employes of this center shared their experience with surgeons from other institutions. Thus, on the basis of trauma department of the City Hospital No 3, the Kyiv City Center for Surgery of the Hand was opened, and the cooperation with other hand surgery departments was established with the assistance of the republican center's specialists.

Development of hand surgery in the western regions of Ukraine began in the 90's. In Lviv, on the initiative of O. Toropovskyi, on the basis of the City Hospital No 8 , the Center of Microsurgery and Surgery of the Hand was created.
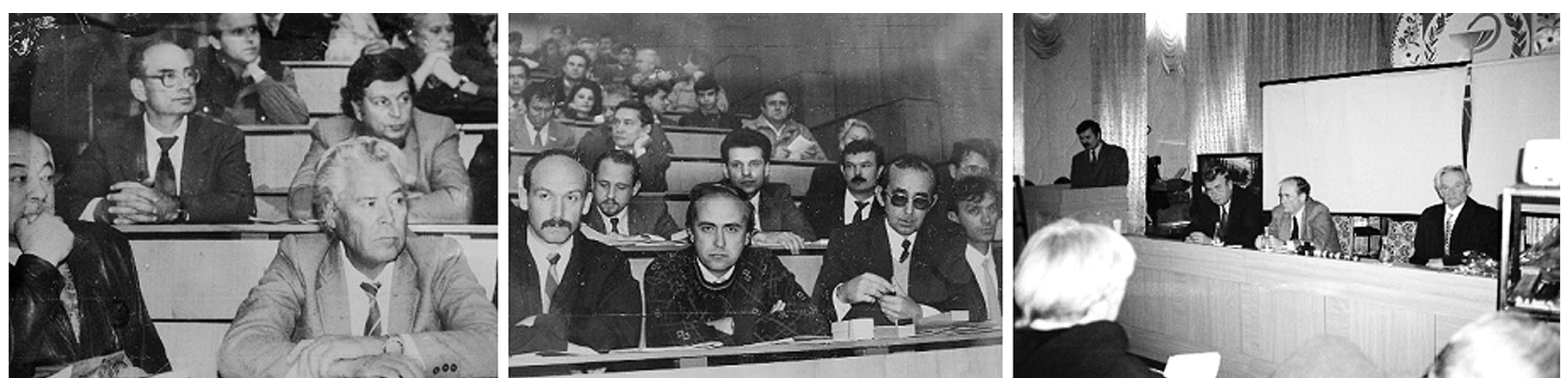

October 1985, first Ukrainian monothematical conference "Treatment of Hand Injuries and their Consequences" 


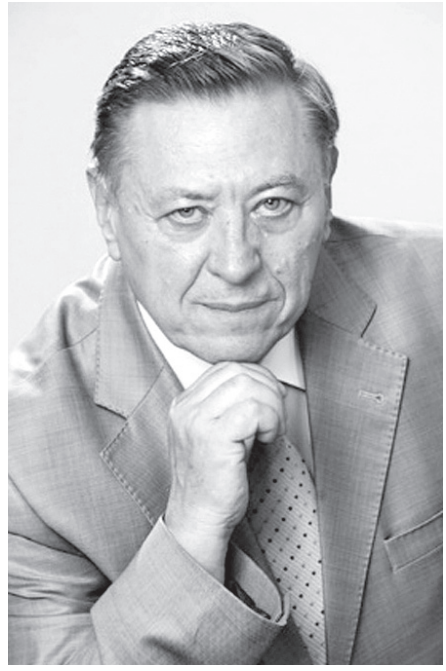

V. Ivchenko

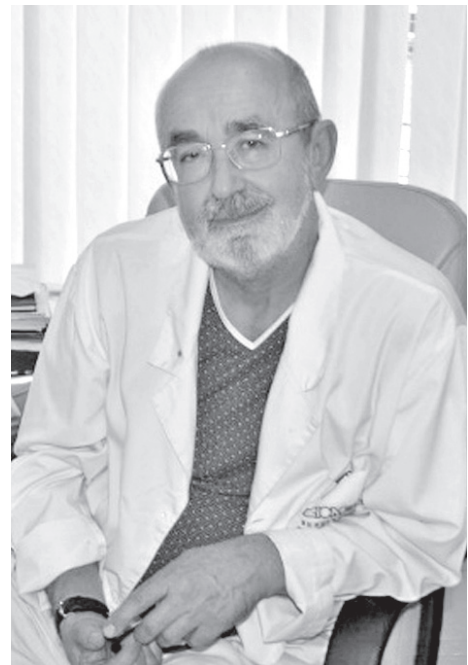

V. Gayovich

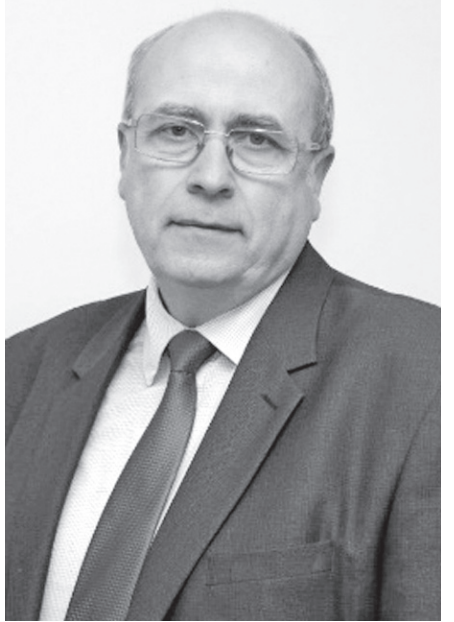

S. Strafun
In Zakarpattia (Uzhhorod), since 1997, on the initiative of V. Haiovich and A. Pogoriliak, microsurgery and hand surgery service was established, which is now under the care of the Combustiology Department. In Volyn (Lutsk), hand surgery service is transmitted to the initiative group, also working at the City Combustiology Center. In IvanoFrankivsk, Chernivtsi, Ternopil and Rivne, initiative groups in the field of hand surgery service have been formed in the structure of orthopedic and trauma departments.

In the 2nd millennium, specialists from the Department of Microsurgery and Reconstructive Surgery of the Upper Extremity (Kyiv) regularly went to the regional and district centers in order to teach and demonstrate surgical interventions, and invite orthopedic and trauma surgeons to study surgery of the hand. The program of monthly training on tendon surgery and some aspects of surgery of the hand was implemented at that time. Dozens of orthopedic and trauma surgeons got specialization in hand surgery according to that program.

2005 was marked by the opening of another center for surgery of the hand in Luhansk on the initiative of $\mathrm{V}$. Ivchenko and under the guidance of V. Holovchenko, whose surgeons owned microsurgical equipment and provided highly skilled assistance to the population of this region.

"Ukrainian Hand Surgery Society" (UHSS) was created in 2012, and led by prof. S. Strafun, as a result of collaboration of all hand surgery centers; in 2014, UHSS

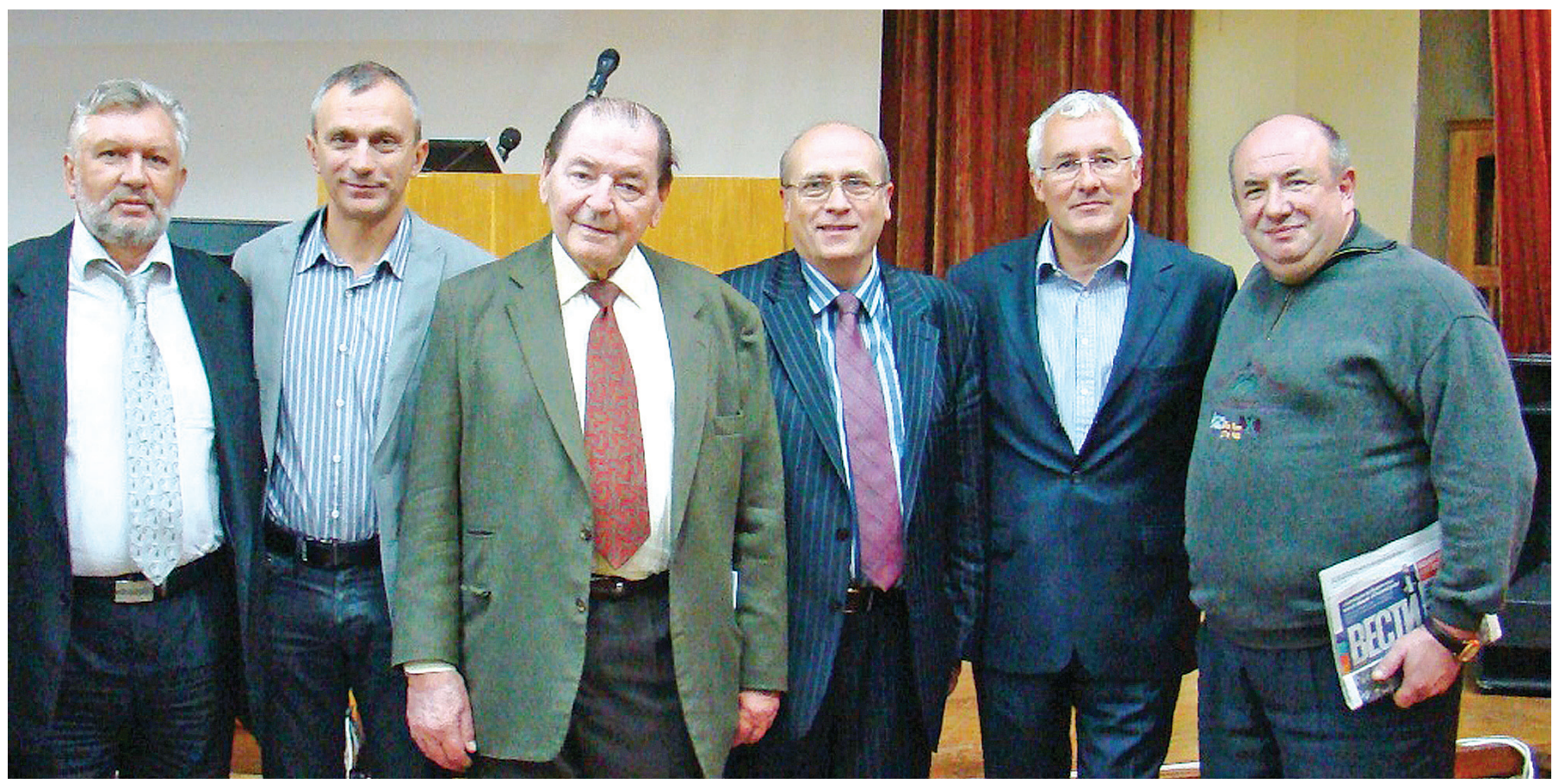

Left to right: O. Borzykh, I. Kurinnyi, H. Millesi, S.Strafun, R. Schmidhammer, V. Leskov 
was accepted into the Federation of European Societies for the Surgery of the Hand (FESSH).

Until 2014, Donetsk and Luhansk had full-profile microsurgery and hand surgery centers, which provided emergency round-the-clock assistance to all people of this and other regions of Ukraine with injuries and diseases of the hand, polystructural extremity trauma, and tissue defects.

Since the beginning of the military conflict at the east of Ukraine, hand surgery department in Luhansk has been destroyed and ransacked, and does not function. The department in Donetsk has lost its high level of qualification, since all leading specialists have moved from occupied territories and work in various centers of Ukraine.

At present, our experts are regular participants in the annual FESSH Congress, and young specialists participate in the FESSH Academy. Due to close scientific and practical communication with European colleagues, leading specialists in microsurgery and reconstructive surgery of the upper extremity are always in the trend of the world's events in the surgery of the hand field.

Several training sessions on tendon surgery and microsurgery have been conducted in Ukraine, with the participation of internationally renowned experts, such as Hanno
Millesi. A regular hands-on practice seminar "Hand surgery course" was started in 2018; since then, a hundred specialists were able to improve their skills in tendon suture, bone osteosynthesis, and use of regenerative technologies in the field of surgery of the hand.

In 2017, I. Kurinnyi was elected as the president of Ukrainian Hand Surgery Society.

Ukrainian hand surgery society uses different methods in order to teach trauma and orthopedic surgeons the surgery of the hand, such as: training courses and seminars, webinars, lectures, presentations in various scientific and scientific-practical forums, publications in professional and popular science magazines, publications of methodological materials and monographs.

We see further perspective in the development and implementation of modern technologies in hand surgery, closer integration with FESSH and directly with the European hand surgery societies. It is important to conduct a variety of training programs with the support of FESSH, both in Ukraine and in other European countries.

Conflict of interest. The authors declare no conflict of interest. This publication has not been, is not and will not be the subject of commercial interest in any form.

\section{Розвиток хірургії кисті в Україні}

Страфунн С.С. ${ }^{1}$, Борзих О.В. ${ }^{2}$, Курінний I.M. ${ }^{1}$, Івченко Д.В. ${ }^{3}$, Білий С.I. ${ }^{4}$,

Тимошенко С.В. ${ }^{1}$, Лєсков В.Г. ${ }^{1}$, Ярова М.Л. ${ }^{1}$, Лисак А.С. ${ }^{1}$

${ }^{1}$ ДУ "Інститут травматологіï та ортопедії НАМН України", м. Київ

${ }^{2}$ Національний військово-медичний клінічний щентр "ГВКГ" МО Украӥни, м. Киёв

${ }^{3}$ КНП "МЛЕ та ШМД" ЗМР, м. Запоріжжя

"КНП "МКЛ № 16" ДМР, м. Дніпро

Резюме. Удругій половині ХХ століття, в період бурхливої індустріалізації, через швидкий розвиток металургійної, гірничої та інженерної промисловості, який супроводжувався високим рівнем травм зі значним рівнем інвалідності, в Донеиькій, Дніпропетровській та Харківській областах виникла потреба у створенні нових підходів до лікування ушкоджень верхньої кінцівки. Новий етап розвитку хірургї кисті та мікрохірургї̈ в Україні розпочався у 1980-х роках: у Києві у 1982 р. на базі ду "Інститут травматології та ортопедї НАМН України" під керівництвом І.Г. Антонюка було створено відділення "Мікрохірургї̈ та реконструктивної хірургії верхнъої кінцівки". Розвиток хірургї кисті у західних областях України розпочався у 1990-х роках. У Львові за інічіативи О.М. Тороповського на базі 8-ї міської лікарні було створено чентр "Мікрохірургї та хірургї кисті". На Закарпатті (Ужгород) iз 1997 року за інічіативи В.І. Гайовича та А.Й. Погоріляка створено службу мікрохірургї та хірургї кисті, яка зараз перебуває під опікою комбустіологічного відділення. На Волині (Луцьк) хірургією кисті займається ініціативна група, яка також працюе в міському центрі комбустіології. В Івано-Франківську, Чернівиях, Тернополі та Рівному - в структурі ортопедичних та травматологічних відділень сформовані ініміативні групи у сфері обслуговування хірургї верхньої кінцівки. 2005 рік відзначився відкриттам Луганського чентру хірургї кисті за інічіативи В.К. Івченка та під керівництвом В.В. Головченко, хірурги якого мали мікрохірургічне обладнання та надавали висококваліфбіковану допомогу населенню щього регіону. "Українська асочіащія хірургї кисті" була створена у 2012 рочі в результаті співпращі всіх центрів хірургї кисті україни, ї периим президентом став 
проф. С.С. Страфун, а в 2014 рощі асоціація стала повноправним членом Федеращї Європейських товариств хірураї кисті (FESSH).

Ключові слова: хірургія кисті; історія хірургї кисті; хірургія кисті в Украӥні.

\section{Развитие хирургии кисти в Украине}

Страфунн С.С. ${ }^{1}$, Борзых А.В. ${ }^{2}$, Куринный И.Н. ${ }^{1}$, Ивченко Д.В. ${ }^{3}$, Билый С.И. ${ }^{4}$, Тимошенко С.В. ${ }^{1}$, Лесков В.Г. ${ }^{1}$, Яровая М.Л. ${ }^{1}$, Лысак А.С. ${ }^{1}$

${ }^{1}$ ГУ "Институт травматологии и ортопедии НАМН Украины", г. Киев

${ }^{2}$ Национальный военно-медицинкий клинический центр "ГВКГ" МО Украины, г. Киев ${ }^{3}$ КНП “ГБЭ и СМП" ЗГС, г. Запорожье

"КНП “ГКБ № 16" ДГС, г. Днепр

Резюме. Во второй половине ХХ века, в период бурной индустриализащии, в результате быстрого развития металлургической, горной и инженерной промышленности, которое сопровождалось высоким уровнем травм со значительным уровнем инвалидности, в Донецкой, Днепропетровской и Харьковской областях возникла потребность в создании новых подходов к лечению повреждений верхней конечности. Новый этап развития хирургии кисти и микрохирургии в Украчне начался в 1980-х годах: в Киеве в 1982 году на базе ГУ "Институт травматологии и ортопедии НАМН Украины" под руководством И.Г. Антонюка было создано отделение "Микрохирургии и реконструктивной хирургии верхней конечности". Развитие хирургии кисти в западных областях Украины началось в 1990-х годах. Во Львове по инициативе А.Н. Тороповского на базе 8-й городской больнищы был создан чентр "Микрохирургии и хирургии кисти". На Закарпатье (Ужгород) с 1997 года по инициативе В.И. Гайовича и А.И. Погориляка создана служба микрохирургии и хирургии кисти, которая сейчас находится под опекой комбустиологического отделения. На Волыни (Луик) хирургией кисти занимается инициативная группа, которая также работает в городском чентре комбустиологии. В Ивано-Франковске, Черновиах, Тернополе и Ровно - в структуре ортопедических и травпатологических отделений сформированы инициативные группы в сфере обслуживания хирургии верхней конечности. 2005 год был отлечен открытием Луганского иентра хирургии кисти по инициативе В.К. Ивченко и под руководством В.В. Головченко, хирурги которого владели микрохирургическим оборудованием и оказывали высококвалифищированную помощь населению этого региона. "Украинская ассощиащия хирургии кисти" была создана в 2012 году в результате сотрудничества всех центров хирургии кисти Украины, ее первым президентом стал проф. С.С. Страфун, а в 2014 году ассощиация стала полноправныи членом Федеращии Европейских обществ хирургии кисти (FESSH).

Ключевые слова: хирургия кисти; история хирургии кисти; хирургия кисти в украине.

\section{Відомості про авторів:}

Страфун Сергій Семенович - член-кореспондент НАМН Украйни, доктор медичних наук, професор, завідувач відділом "Мікрохірургії та реконструктивно-відновної хірургії верхнъої кінцівки" ду "Інститут травматології та ортопедії НАмН Украйни", вул. Бульварно-Кудрявська, 27, Київ, 01601, Україна.E-mail: strafun-s@ukr.net. ORCID: bttps://orcid.org/0000-0001-8178-9290.

Борзих Олександр Володимирович - доктор медичних наук, професор Начіонального військово-медичнного клінічного центру “ГВКГ" МО Украйни, вул. Госпітальна, 16, Київ, 02000, Укpaïra.E-mail: natashabor@ukr.net.

Курінний Ігор Миколайович - доктор медичних наук, провідний науковий співробітник відділу "Мікрохірургї та реконструктивно-відновної хірургії верхнъої кінцівки" Ду“Інституттравматологіїтаортопедї̈НАМНУкраїни", вул. Бульварно-Кудрявська, 27, Küв, 01601, Україна.E-mail: ignikur@gmail.com.

Івченко Дмитро Валерійович - доктор медичних наук, директор КНП "МЛЕ та ШМД" ЗМР КНП "МЛЕ та ШМД" ЗМР, вул. Перемоги, 80, Запоріжжя, 69000, Украӥна. 
Білий Сергій Іванович - кандидат медичних наук, завідувач Міжобласним центром хірургї кисті КНП “МКЛ №16” ДМР, КНП “МКЛ №16” ДМР, просп. Богдана Хмельнищького, 19, Дніпро, 49069, Украӥна.

тимошенко Сергій Вікторович - кандидат медичних наук, науковий співробітник відділу "Мікрохірургї та реконструктивно-відновної хірургї̈ верхнъої кінщівки" ду "Інститут травматологї та ортопедії НАМН україни", вул. БульварноКудрявська, 27, Київ, 01601, Україна.E-mail: setym@ukr.net. ORCID: https://orcid. org/0000-0001-6384-4153.

Лєсков Володимир Григорович - кандидат медичних наук, лікар ортопед-травматолог відділу "Мікрохірургії та реконструктивно-відновної хірургії верхнъої кінцівки" ду "Інститут травматологї та ортопедї НАМН України", вул. Бульварно-Кудрявська, 27, Київ, 01601, Україна.

Ярова Марина Леонідівна - кандидат медичних наук, науковий співробітник науково-організаціичного методичного відділу ДУ "Інститут травматології та ортопедї НАмН України”, вул. Бульварно-Кудрявська, 27, Київ, 01601, Україна. E-mail: iarova. marina@gmail.com. ORCID: bttps://orcid.org/0000-0002-0029-3611.

Лисак Андріи Сергіиович - лікар ортопед-травматолог науково-організаційного методичного відділу Ду "Інститут травматології та ортопедії НАМН України", вул. Бульварно-Кудрявська, 27, Київ, 01601, Україна. E-mail: dr.andrew.lysak@gmail.com. ORCID: bttps://orcid.org/0000-0001-9042-8884.

\section{Information about authors:}

Strafun Serbii Semenovych - corresponding member of NAMS of Ukraine, D.Med.Sc., professor, head of the Department of Microsurgery and Reconstructive Surgery of the Upper Extremity, SI "Institute of Traumatology and Orthopedics of NAMS of Ukraine", 27 BulvarnoKudriavska St., Kyiv, 01601, Ukraine.E-mail: strafun-s@ukr.net. ORCID: https://orcid. org/0000-0001-8178-9290.

Borzykh Oleksandr Volodymyrouych - D.Med.Sc., professor at the National Military Medical Clinical Center "Main Military Clinical Hospital" of the Ministry of Defense of Ukraine, 16 Hospitalna St., Kyiv, 02000,Ukraine.E-mail:natashabor@ukr.net.

Kurinnyi Ihor Mykolaioyych - D.Med.Sc., leading researcher at the Department of Microsurgery and Reconstructive Surgery of the Upper Extremity, SI "Institute of Traumatology and Orthopedics of NAMS of Ukraine", 27 Bulvarno-Kudriavska St., Kyiv, 01601, Ukraine. E-mail: ignikur@gmail.com.

Ivchenko Dmytro Valeriiouych - D.Med.Sc., professor, director of the MNE "Emergency and Ambulance City Hospital" of Zaporizhshia City Council, 80 Peremohy St., Zaporizhzhia, 69000, Ukraine.

Bilyi Serbii Ivanouych - Ph.D. in Medicine, head of the Interregional Center of Surgery of the Hand, MNE "City Clinical Hospital No 16" of the Dnipro City Council, 19 Bobdan Kbmelnytskyi Ave., Dnipro, 49069, Ukraine.

Tymoshenko Serbii Viktorouych - Ph.D. in Medicine, researcher at the Department of Microsurgery and Reconstructive Surgery of the Upper Extremity, SI "Institute of Traumatology and Orthopedics of NAMS of Ukraine", 27 Bulvarno-Kudriavska St., Kyiv, 01601, Ukraine. E-mail: setym@ukr.net. ORCID: bttps://orcid.org/0000-0001-6384-4153.

Lieskov Volodymyr Hryborovych - Ph.D. in Medicine, orthopedic traumatologist at the Department of Microsurgery and Reconstructive Surgery of the Upper Extremity, SI "Institute of Traumatology and Orthopedics of NAMS of Ukraine", 27 Bulvarno-Kudriavska St., Kyiv, 01601, Ukraine.

Yarova MarynaLeonidivna - Ph.D. in Medicine, researcher at the Scientific and Organizational Methodological Department, SI "Institute of Traumatology and Orthopedics of NAMS of Ukraine", 27 Bulvarno-Kudriavska St., Kyiv, 01601, Ukraine.E-mail: iarova.marina@gmail.com. ORCID: bttps://orcid.org/0000-0002-0029-3611.

Lysak Andrii Serbiiouych - orthopedic traumatologist at the Scientific and Organizational Methodological Department, SI "Institute of Traumatology and Orthopedics of NAMS of Ukraine", 27 Bulvarno-Kudriavska St., Kyiv, 01601, Ukraine. E-mail: dr.andrew.lysak@gmail.com. ORCID: bttps://orcid.org/0000-0001-9042-8884. 


\section{Сведения об авторах:}

Страфун Сергей Семенович - член-корреспондент НАМН Украины, доктор медищинских наук, профессор, заведуюшии отделением "Микрохирургии и реконструктивновосстановительной хирургии верхней конечности" Гу "Институт травматологии и ортопедии НАМН Украины", ул. Бульварно-Кудрявская, 27, Киев, 01601, Украина. E-таil: strafun-s@ukr.net. ORCID: bttps://orcid.org/0000-0001-8178-9290.

Борзых Александр Владимирович - доктор медищинских наук, профессор Нащионального военно-медицинского клинического чентра "ГВКГ" МО Украины, ул. Госпитальная, 16, Киев, 02000, Украина.E-mail: natashabor@ukr.net.

Куринной Игорь Николаевич - доктор медииинских наук, ведущий научный сотрудник отделения "Микрохирургии и реконструктивно-восстановительной хирургии верхней конечности" Гу "Институт травматологии и ортопедии НАМН Украины", ул. Бульварно-Кудрявская, 27, Киев, 01601, Украина.E-mail: natashabor@ukr.net.

Ивченко Дмитрий Валерьевич - доктор медицинских наук, профессор, директор КНП “ГБЭ и СМП" ЗГС, ул. Победы, 80, Запорожье, 69000, Украина.

Билыи Сергей Иванович - кандидат медицинских наук, заведующии Межобластным центром хирургии кисти КНП “ГКБ № 16” ДГС, просп. Богдана Хмельницкого, 19, Днепр, 49069, Украина.

Тимошенко Сергей Викторович - кандидат медиинских наук, научный сотрудник отделения "Микрохирургии и реконструктивно-восстановительной хирургии верхней конечности" Гу "Институт травматологии и ортопедии НАМН Украины", ул. Бульварно-Кудрявская, 27, Киев, 01601, Украина. E-mail: setym@ukr.net. ORCID: bttps://orcid.org/0000-0001-6384-4153.

Лесков Владимир Григорьевич - кандидат медищинских наук, врач ортопед-травматолог отделения "Микрохирургии и реконструктивно-восстановительной хирургши верхней конечности" ГУ "Институт травматологши и ортопедии НАМН Украины", ул. Бульварно-Кудрявская, 27, Киев, 01601, Украина.

яровая Марина Леонидовна - кандидат медииинких наук, научный сотрудник научно-организащионного методического отделения Гу "Институт травматологии и ортопедии НАМН Украины”, ул. Бульварно-Кудрявская, 27, Киев, 01601, Украина. E-таil: iarova.marina@gmail.com. ORCID: bttps://orcid.org/0000-0002-0029-3611.

Лысак Андрей Сергеевич - врач ортопед-травматолог научно-организащионного методического отделения ГУ "Институт травматологии и ортопедии НАМН Украины", ул. Бульварно-Кудрявская, 27, Киев, 01601, Украина. E-mail: dr.andrew.lysak@gmail.com. ORCID: bttps://orcid.org/0000-0001-9042-8884.

Для кореспонденціі: Лисак Андрій Сергійович, лікар ортопед-травматолог ДУ "Інститут травматології та ортопедії НАМН України", вул. Бульварно-Кудрявська, 27, Київ, 01601, Україна. Тел. +38(095)4296942. E-mail: dr.andrew.lysak@gmail.com.

For correspondence: Lysak Andrii S., orthopedic traumatologist at the Scientific and Organizational Methodological Department, SI "Institute of Traumatology and Orthopedics of NAMS of Ukraine", 27 Bulvarno-Kudriavska St., Kyiv, 01601, Ukraine. Tel. +38(095)4296942. E-mail: dr.andrew.lysak@gmail.com.

Для корреспонденции: Лысак Андрей Сергеевич, врач ортопед-травматолог ГУ "Институт травматологии и ортопедии НАМН Украины", ул. Бульварно-Кудрявская, 27, Киев, 01601, Украина. Тел. +38(095)4296942. E-mail: dr.andrew.lysak@gmail.com. 